\title{
Genetic basis of diabetic kidney disease and other diabetic complications
}

\author{
Sandholm, Niina
}

2018-06

Sandholm , N \& Groop , P-H 2018 , ' Genetic basis of diabetic kidney disease and other diabetic complications ' , Current Opinion in Genetics \& Development, vol. 50 , pp. 17-24 . https://doi.org/10.1016/j.gde.2018.01.002, https://doi.org/10.1016/j.gde.2018.01.002

http://hdl.handle.net/10138/311414

https://doi.org/10.1016/j.gde.2018.01.002

cc_by_nc_nd

acceptedVersion

Downloaded from Helda, University of Helsinki institutional repository.

This is an electronic reprint of the original article.

This reprint may differ from the original in pagination and typographic detail.

Please cite the original version. 


\section{Genetic basis of diabetic kidney disease and other diabetic complications}

Current Opinion in Genetics and Development, Issue 50, Molecular and genetic basis of disease

Niina Sandholm ${ }^{a, b, c}$ and Per-Henrik Groop a,b,c,d

a. Folkhälsan Institute of Genetics, Folkhälsan Research Center, 00290 Helsinki, Finland

b. Abdominal Center Nephrology, University of Helsinki and Helsinki University Hospital, 00290 Helsinki, Finland

c. Research Programs Unit, Diabetes and Obesity, University of Helsinki, 00290 Helsinki, Finland

d. Department of Diabetes, Central Clinical School, M onash University, M elbourne, Victoria, Australia

\section{Corresponding author:}

Niina Sandholm, DSc (Tech)

FinnDiane Study Group

Folkhälsan Institute of Genetics, Folkhälsan Research Center

Postal Address:

Biomedicum C329b

Haartmaninkatu 8

00290 Helsinki

Finland

Tel. +358 919125695

Fax +358 919125382

niina.sandholm@helsinki.fi

\section{Word count: $\mathbf{2 4 7 6}$ words}

\section{Figures: 1}

\section{Boxes: 2}

\section{Abstract (169 words)}

Diabetic kidney disease and other long-term complications are common in diabetes, and comprise the main cause of co-morbidity and premature mortality in individuals with diabetes. While familial clustering and heritability have been reported for all diabetic complications, the genetic background and the molecular mechanisms remain poorly understood. In recent years, genome-wide association studies have identified a few susceptibility loci for the renal complications as well as for diabetic retinopathy, diabetic cardiovascular disease and mortality. As for many complex diseases, the genetic factors increase the risk of complications in concert with the environment, and certain associations seem specific for particular conditions, e.g. SP3CDCA7 associated with end-stage renal disease only in women, or MGMT and variants on chromosome $5 q 13$ associated with cardiovascular mortality only under tight glycaemic control. The characterization of the phenotypes is one of the main challenges for genetic research on diabetic complications, in addition to an urgent need to increase the number of individuals with diabetes with high quality phenotypic data to be included in future genetic studies.

Key words: Diabetic kidney disease; diabetic nephropathy; genome-wide association study; GWAS; end stage renal disease; whole exome sequencing; diabetic retinopathy; cardiovascular disease 
Diabetes is a true epidemic with 415 million adults with diabetes worldwide[1]. One third of these patients develop severe microvascular complications such as diabetic kidney disease (DKD), sight threatening diabetic retinopathy (DR), and diabetic neuropathy. Furthermore, individuals with diabetes carry an increased risk of cardiovascular disease (CVD), a risk that is particularly high in those with DKD. Consequently, those that develop end stage renal disease (ESRD) requiring dialysis or kidney transplant for survival have 18 times higher premature mortality compared with the general population [2].

Although there is strong evidence for a genetic influence on the development of diabetic complications, environmental factors such as exposure to high blood glucose also contribute, and the disease outcomes are likely a complex interplay between genetics, epigenetic gene regulation, and environment. In this review, we will highlight recent large-scale genetic studies on various diabetic complications. Apart from improving our understanding of the molecular mechanisms behind the diabetic complications, the genetic findings also hold promise of identifying novel biomarkers for earlier identification of patients at risk, and novel therapeutic target molecules.

\section{Diabetic kidney disease}

Diabetic kidney disease (DKD) clusters in families [3,4]. While the 25-year cumulative incidence of DKD was $25 \%$ in diabetic siblings of probands without DKD, the risk was $43 \%$ and $58 \%$ in siblings of probands with DKD or ESRD, respectively, resulting in a more than twofold sibling risk ratio for DKD [5]. Recently, by using genome-wide genotyping data of unrelated individuals, the narrow sense heritability of DKD was estimated to be $35 \%[6]$.

\section{Genome-wide association studies on DKD}

M ultiple candidate genes have been studied for DKD, but robust replication has been challenging $[7,8]$. One of the first genome-wide association studies (GWAS) on DKD suggested association at rs 10868025 in the FRMD3 gene $\left(p=5.0 \times 10^{-7}\right)[9]$, and the finding was supported by many [9-11], although not all subsequent studies $[6,8]$. The first genome-wide significant findings for ESRD were reported from a GWAS meta-analysis from the GEnetics of Nephropathy - an International Effort (GENIE) consortium including 6691 individuals with T1D from three discovery cohorts, and up to 11,847 individuals in the joint meta-analysis including the replication cohorts. Variants in the AFF3 ( $r 57583877, p=1.2 \times 10^{-8}$ ) and on the RGM A - MCTP2 gene region ( $r$ 12437854, $p=2.0 \times 10^{-9}$ ) were associated with ESRD (Figure 1), while suggestive evidence of association with DKD was found for variants in the ERBB4 gene ( $r 57588550 p=2.1 \times 10^{-7}$ ) [12].

A gender-stratified GWAS identified variants between the SP3 and CDCA7 genes to be associated with ESRD in women with T1D, and the finding replicated in other GENIE cohorts (rs4972593 $p=3.9 \times 10^{-8}$ )[13]. Intriguingly, the nearby SP3 shows higher expression in female glomeruli (top 0.3\%), and Sp3 transcription factor directly binds to estrogen receptor $\alpha$, providing a plausible explanation for the gender-specific association.

Urinary albumin excretion rate (AER) is one of the early signs of renal complications in diabetes, and commonly used to diagnose and classify DKD. A GWAS on AER in 1925 individuals with T1D from the Finnish Diabetic Nephropathy Study (FinnDiane) found variants in the GLRA3 gene associated with AER (rs1564939 $\left.p=8.4 \times 10^{-9}\right)$, however, replication in non-Finnish Europeans showed a trend in the opposite direction $(p=0.03)$, suggesting a population specific effect[14]. Replication in further Finnish individuals is ongoing to confirm the finding.

A trans-ethnic GWAS meta-analysis with 6197 individuals with T2D identified rs12523822 on the SCAF8/CNKSR3 locus associated with DKD with a particularly strong effect seen in American Indians $\left(p=5.7 \times 10^{-9}\right.$, odds ratio $\left.(O R)=0.57\right)$. Furthermore, variants in the MYH9 locus were near genome-wide significant in the African American group, likely due to a large proportion of the individuals with T2D with 
co-occurring non-diabetic renal disease, as MYH9 is one of the main susceptibility loci for ESRD in the general population with African ancestry [15].

GWAS on estimated glomerular filtration rate (eGFR) in 133,413 individuals from the general population identified 53 loci for eGFR. The rs12917707 in the UM OD gene was significantly associated with eGFR also in the subset of 16,477 individuals with diabetes (mainly T2D). Nominal association $(p \varangle 0.05$ ) was found in the subset of individuals with diabetes for 19 of the lead loci [16]. Whereas nearly all individuals with T1D and DKD show histological findings characteristic of diabetic nephropathy, in T2D only 30-50\% of individuals with albuminuria have true DKD, while the rest may have kidney disease related to hypertension, overweight or ageing [17]. Thus, the genetic factors affecting eGFR in the general population may also contribute to the renal complications in individuals with T2D, while little overlap is found in T1D.

A recent GWAS in 5156 individuals with T1D from the SUrrogate markers for Micro- and Macro-vascular hard endpoints for Innovative diabetes Tools (SUM M IT) consortium utilised multiple phenotypic definitions based on various thresholds of either AER, eGFR, or both [6]. No locus reached genome-wide significance after joint analysis including 12,540 individuals, but variants in the previously reported AFF3 were among the lead SNPs; of note, there was a substantial overlap between this and the previous studies. Variants associated with T2D and body mass index (BMI) were associated with DKD, suggesting that metabolic changes leading to $\mathrm{T} 2 \mathrm{D}$, and $\mathrm{BMI}$, are causal risk factors for DKD. Furthermore, there was an inverse genome-wide correlation between DKD and smoking cessation.

For many complex diseases, the number of loci has increased after including some tens of thousands of individuals. Larger GWAS meta-analyses on DKD are underway e.g. in the JDRF - DNCRI (JN Todd, abstract in Diabetes 2016, 65: A100), and in the SUM MIT consortium (NW Rayner, abstract in Diabetologia 2015, 58: S200).

Taking advantage of genetic data, a causal link was reported between BMI and DKD in a Mendelian randomization study, which utilises genetic information to infer causality between a biomarker and an outcome [18]. Similar studies reported kidney injury molecule 1 (KIM-1) as a likely causal risk factor for reduced eGFR [19], while no evidence of causal link was found for serum uric acid [20].

\section{Whole exome sequencing for DKD}

While the GWASs are best suited for detecting common genetic variants, many of the low frequency and rare variants can only be captured with sequencing based methods such as whole exome and whole genome sequencing (WES and WGS). While WES only covers the protein coding regions of the genome, it is more affordable than WGS; furthermore, as the non-synonymous exon variants may directly affect the protein function, their effect sizes, and thus the statistical power, may be markedly higher than for intronic or intergenic variants affecting regulation of gene expression, making WES an attractive research strategy. Nevertheless, findings from WES and WGS on DKD remain sparse. In WES including 997 T1D individuals from the SUM M IT consortium, a rare intronic variant rs188427269 in the NVL gene reached exome-wide significance $\left(p<5 \times 10^{-7}\right)$ for association with ESRD, but no coding variant reached this threshold and further replication is required to validate this finding [6]. Nevertheless, preliminary results are also emerging from WGS in siblings with and without DKD (Öhman M K, abstract in J Am Soc Nephrol 2016, 27:429A). 


\section{Box 1: Research gaps for genetics of DKD}

- Need of larger patient cohorts for genetic studies in order to increase power and likelihood of finding susceptibility loci

- Better phenotypic characterization of the renal complications, preferably by promoting collection of renal biopsies, since currently used biomarkers eGFR and AER can serve at the most as intermediate phenotypes and do not provide a fully accurate description of the renal pathology

- Gene expression and eQTL data for cell-specific kidney tissue are limited, hampering functional annotation of identified variants

\section{Diabetic Retinopathy (DR)}

Also, DR clusters in families [21], and heritability estimates range from 25 to $52 \%[22,23]$. In a meta-analysis of candidate genes, only variants in the aldose reductase AKR1B1 gene were associated with $D R\left(p=1 \times 10^{-}\right.$ $\left.{ }^{4}\right)$ [24]. Recently, in a thiamine (vitamin $B_{1}$ ) transporter candidate gene study, variants in SLC19A3 were associated with reduced risk of $\mathrm{DR}$, and the association reached genome-wide significance for the combined microvascular endpoint (DR and ESRD) in meta-analysis with replication samples (rs12694743 $\left.p=7.1 \times 10^{-9}\right)[25]$.

Multiple GWASs have been performed on DR in various ethnicities [26-31], but the studies are limited in size (mainly few hundreds of individuals) and only one GWAS meta-analysis exists with 2829 individuals from two studies [27]. Since many of the studies have only reported suggestive signals with no replication, subsequent studies have attempted to replicate the loci but with limited success. Nominally significant replication $(p \varangle 0.05$ ) was obtained e.g. for variants in ARHGAP22[32] and PLXDC2[33] that originally showed significant genome-wide association with DR in Taiwanese individuals with T2D[28], but no replication was achieved in other studies [31,34].

GWAS on DR in 844 Australian individuals with T2D found rs9896052 near GBR2 gene to be suggestively associated with DR $\left(p=6.6 \times 10^{-5}\right)$, and this finding was replicated in people with T1D, T2D, and in an Indian cohort of individuals with T2D, resulting in genome-wide significance in meta-analysis $\left(p=4.2 \times 10^{-8}\right)$. In human histological samples, the GBR2 protein was expressed throughout the retina, and GBR2 expression was increased in a mouse model of DR[31].

WES including 107 Saudi-Arabian individuals with T2D found enrichment of rare variants in those without DR in the NME3, LOC728699, and FASTK genes $\left(p<5 \times 10^{-8}\right)$ [35]. Another WES including 70 individuals of mixed ethnicity and mainly T2D, suggested six genes with rare variants in DR cases and reduced gene expression in human retinal endothelial cells, when cultured under high glucose [36]. However, findings from both studies require replication for validation of the association.

\section{Box 2: Research gaps in genetics of DR}

- Published GWASs are small and only one GWAS meta-analysis exists with 2829 individuals [27]

- Scoring of fundus photographs is relatively straightforward but demanding, and access to carefully scored high quality fundus photographs is limiting the study population. 


\section{Neuropathy}

Diabetic neuropathies cover a range of symptoms and can be divided into diabetic peripheral neuropathies including painful neuropathy, and autonomic neuropathy [37]. However, diagnosis and phenotyping for research purposes is challenging, and the genetic background remains largely unexplored soil. Literature based meta-analysis of ACE and MTHFR candidate genes in nine studies found nominal evidence of association with peripheral neuropathy for both genes [38]. Using genome-wide genotyping data, the heritability of painful neuropathy was estimated to be 11\% [39]. The same GWAS study, including 3063 individuals with T2D, suggested variants near GFRA2 to confer susceptibility to painful neuropathy ( $\left.r s 17428041 p=1.8 \times 10^{-7}\right)$ [39]. Further stratification by gender in the same study suggested $r s 71647933$ at the ZSCAN20-TLR12P to be associated with painful neuropathy in women $\left(p=2.7 \times 10^{-7}\right)$, and $r 56986153$ near HMGB1P46 in men $\left(p=8.0 \times 10^{-7}\right)[40]$. Another GWAS on painful neuropathy in individuals with T1D is underway (E Valo, abstract in Diabetologia 2017, 60: S72-S73).

\section{Cardiovascular complications in diabetes}

The risk of CVD is particularly elevated in those with DKD with $40 \%$ developing CVD by the age of 40 , compared to 7\% among people with T1D without DKD [41]. Nevertheless, the genetic background of CVD in diabetes has been studied surprisingly little, despite evidence of familial clustering [42] and high heritability (41\%) for intima media thickness, a marker of atherosclerosis [43].

There is evidence that the susceptibility loci for CVD in the general population also affect the risk of CVD in individuals with diabetes[44,45]. On the contrary, a GWAS including 4188 individuals with T2D identified rs10911021 near the glutamate-ammonia ligase (GLUL) gene encoding a glutamine synthetase, to be associated with CVD especially in individuals with diabetes $\left(p=2 \times 10^{-8}\right)[46]$. Of note, the lead SNP was associated with GLUL expression in endothelial cells, and with the ratio between the glutamic acid precursor (plasma pyroglutamic acid) and glutamic acid, pointing to a potential mechanism[46].

In a GWAS of 2667 individuals with T2D from the intensive treatment arm of the ACCORD study targeting glycated hemoglobin $\mathrm{HbA}_{1 c}$ levels of $\varangle 6.0 \%$, minor alleles at rs9299870 in MGMT and rs57922 on chromosome $5 q 13$ were associated with three-fold risk of cardiovascular mortality [47]. Despite the specific design of the discovery study, supporting evidence for the joint effect of the two variants on cardiovascular mortality under tight glycemic control was also found in two other studies. When 65 biomarkers were evaluated in a subset of 351 individuals from the ACCORD study, rs57922 was associated with the 12month change in the active glucagon-like peptide 1 (GLP-1) in the intensive treatment arm, with increased GLP-1 levels in the C/C homozygotes that derived benefit from intensive glycemic control [48].

While preliminary results have been presented for further GWAS meta-analyses on coronary artery disease (N Van Zuydam, abstract in Diabetologia 2013, 56:S76-77) and peripheral vascular disease in individuals with diabetes (N Van Zuydam, abstract in Diabetes 2015, 64:A15-A15), no GWASs are published for cerebrovascular disease (strokes) in diabetes.

\section{Conclusions}

GWASs have thus far identified six susceptibility loci for renal complications in diabetes ( $p<5 \times 10^{-8}$ for AFF3, RGMA-MCTP2, and CDCA7-SP3 for ESRD; SCAF8-CNKSR3 for DKD; UMOD for eGFR; and GLRA3 for albuminuria in Finnish individuals). Furthermore, variants in the GBR2 locus are associated with DR, variants near GLUL with CVD in diabetes and M GMT and $5 q 13$ with cardiovascular mortality under tight glycemic control. However, compared with many other complex diseases, the number of identified loci remains limited. 
Larger number of individuals is required to robustly identify additional loci with moderate effect sizes. Therefore, international collaboration is indispensable. On the other hand, studying well characterized homogenous populations such as Finland or Iceland may be particularly advantageous especially when searching for rare variants; while the population isolates have less variant loci in total, the existing loss-offunction and missense mutations may have markedly higher frequencies, facilitating the identification of novel loci [49].

One of the main challenges in the genetic studies for all microvascular complications is the definition of the phenotype. While multiple markers are used for characterization of the complications, e.g. eGFR and albuminuria for DKD, confirmation of diabetic nephropathy as the underlying pathology would require renal biopsies, which are rarely taken from individuals with diabetes.

As for all complex diseases, the genes do not alone cause disease, but increase the risk in concert with environmental factors. It can be challenging to disentangle the genetic factors under such complex environmental influence, and there is evidence that certain genetic effects are only observed under particular conditions, e.g. SP3-CDCA7 associated with ESRD only in women[13], or M GM T and chromosome $5 q 13$ associated with cardiovascular mortality only under tight glycemic control [47]. Given an unlimited number of patients, these associations might also be observed in non-stratified patient sets, but smaller number of patients is required when only the affected homogenous subpopulation is studied.

Epigenetic changes have been suggested to be the mechanism behind metabolic memory, i.e. sustained effect of hyperglycemia on development of complications over time. Genome-wide DNA methylation studies have shown differently methylated genes for both DKD [50] and DR [51], but further studies are needed before any methylation marks can be used as biomarkers for prediction of complications.

Whilst waiting for whole genome sequencing data for all individuals with diabetes, the genetic research should focus on large GWASs, exome chips, and WES studies in carefully characterized patient sets, aiming to understand the molecular mechanisms and pathophysiology of diabetic complications.

\section{Funding}

This work was supported by Folkhälsan Research Foundation, the Wilhelm and Else Stockmann Foundation, the Liv och Hälsa Foundation, Helsinki University Central Hospital Research Funds (EVO), the Signe and Ane Gyllenberg Foundation, Finska Läkaresällskapet, the Novo Nordisk Foundation (NNF14SA0003), and the Academy of Finland (134379 and 275614). 


\section{References}

Recent publications with special $(\bullet)$ and outstanding $(\bullet \bullet)$ interest are annotated

1. Ogurtsova K, da Rocha Fernandes JD, Huang Y, Linnenkamp U, Guariguata L, Cho NH, Cavan D, Shaw JE, M akaroff LE: IDF Diabetes Atlas: Global estimates for the prevalence of diabetes for 2015 and 2040. Diabetes Res Clin Pract 2017, 128:40-50 doi: S0168-8227(17)30375-3 [pii].

2. Groop PH, Thomas M C, M oran JL, Wadèn J, Thorn LM , M äkinen VP, Rosengård-Bärlund M, Saraheimo M, Hietala K, Heikkilä O, Forsblom C, FinnDiane Study Group: The presence and severity of chronic kidney disease predicts all-cause mortality in type 1 diabetes. Diabetes 2009, 58:1651-1658.

3. Seaquist ER, Goetz FC, Rich S, Barbosa J: Familial clustering of diabetic kidney disease. N Engl J M ed 1989, 320:1161-1165.

4. Borch-Johnsen K, Norgaard K, Hommel E, M athiesen ER, Jensen JS, Deckert T, Parving HH: Is diabetic nephropathy an inherited complication. Kidney Int 1992, 41:719-722.

5. Harjutsalo V, Katoh S, Sarti C, Tajima N, Tuomilehto J: Population-based assessment of familial clustering of diabetic nephropathy in type 1 diabetes. Diabetes 2004, 53:2449-2454.

6••. Sandholm N, Van Zuydam N, Ahlqvist E, Juliusdottir T, Deshmukh HA, Rayner NW, Di Camillo B, Forsblom C, Fadista J, Ziemek D, Salem RM, Hiraki LT, Pezzolesi M, Tregouet D, Dahlstrom E, Valo E, Oskolkov N, Ladenvall C, M arcovecchio M L, Cooper J, Sambo F, M alovini A, M anfrini M, M CKnight AJ, Lajer M, Harjutsalo V, Gordin D, Parkkonen M, FinnDiane Study Group, Jaakko Tuomilehto, Lyssenko V, M cKeigue PM , Rich SS, Brosnan MJ, Fauman E, Bellazzi R, Rossing P, Hadjadj S, Krolewski A, Paterson AD, DCCT/EDIC Study Group, Jose C. Florez, Hirschhorn JN, M axwell AP, GENIE Consortium DD, Cobelli C, Colhoun HM , Groop L, M CCarthy M I, Groop PH, SUM M IT Consortium: The Genetic Landscape of Renal Complications in Type 1 Diabetes. J Am Soc Nephrol 2017, 28:557-574 doi:

10.1681/ASN.2016020231 [doi]. GWAS on DKD with multiple phenotypic definitions showing gentic correlation with BMI, T2D and smoking cessation, as well as and whole exome sequencing on DKD.

7. M ooyaart A, Valk EJJ, van Es L, Bruijn J, de Heer E, Freedman B, Dekkers O, Baelde H: Genetic associations in diabetic nephropathy: a meta-analysis. Diabetologia 2011, 54:544-553.

8. Williams WW, Salem RM, M cKnight AJ, Sandholm N, Forsblom C, Taylor A, Guiducci C, M cAteer JB, M cKay GJ, Isakova T, Brennan EP, Sadlier DM , Palmer C, Soderlund J, Fagerholm E, Harjutsalo V, Lithovius R, Gordin D, Hietala K, Kyto J, Parkkonen M, Rosengard-Barlund M, Thorn L, Syreeni A, Tolonen N, Saraheimo M, Waden J, Pitkaniemi J, Sarti C, Tuomilehto J, Tryggvason K, Osterholm AM, He B, Bain S, Martin F, Godson C, Hirschhorn JN, Maxwell AP, Groop PH, Florez JC, GENIE Consortium: Association testing of previously reported variants in a large case-control meta-analysis of diabetic nephropathy. Diabetes 2012, 61:2187-2194 doi: 10.2337/db11-0751. 
9. Pezzolesi M G, Poznik GD, Mychaleckyj JC, Paterson AD, Barati MT, Klein JB, Ng DPK, Placha G, Canani LH, Bochenski J, Waggott D, M erchant M L, Krolewski B, M irea L, Wanic K, Katavetin P, Kure M, Wolkow P, Dunn JS, Smiles A, Walker WH, Boright AP, Bull SB, 'DCCT/EDIC Research Group', Doria A, Rogus JJ, Rich SS, Warram JH, Krolewski AS: Genome-wide association scan for diabetic nephropathy susceptibility genes in type 1 diabetes. Diabetes 2009, 58:1403-1410.

10. Pezzolesi MG, Jeong J, Smiles AM, Skupien J, Mychaleckyj JC, Rich SS, Warram JH, Krolewski AS: Familybased association analysis confirms the role of the chromosome 9q21.32 locus in the susceptibility of diabetic nephropathy. PLoS One 2013, 8:e60301 doi: 10.1371/journal.pone.0060301 [doi].

11. Freedman BI, Langefeld CD, Lu L, Divers J, Comeau ME, Kopp JB, Winkler CA, Nelson GW, Johnson RC, Palmer ND, Hicks PJ, Bostrom MA, Cooke JN, M cDonough CW, Bowden DW: Differential effects of MYH9 and APOL1 risk variants on FRMD3 Association with Diabetic ESRD in African Americans. PLOS Genet 2011, 7:e1002150 doi: 10.1371/journal.pgen.1002150; 10.1371/journal.pgen.1002150.

12. Sandholm N, Salem RM, M cKnight AJ, Brennan EP, Forsblom C, Isakova T, McKay GJ, Williams WW, Sadlier DM, Makinen VP, Swan EJ, Palmer C, Boright AP, Ahlqvist E, Deshmukh HA, Keller BJ, Huang H, Ahola AJ, Fagerholm E, Gordin D, Harjutsalo V, He B, Heikkila O, Hietala K, Kyto J, Lahermo P, Lehto M, Lithovius R, Osterholm AM , Parkkonen M, Pitkaniemi J, Rosengard-Barlund M, Saraheimo M, Sarti C, Soderlund J, Soro-Paavonen A, Syreeni A, Thorn LM , Tikkanen H, Tolonen N, Tryggvason K, Tuomilehto J, Waden J, Gill GV, Prior S, Guiducci C, M irel DB, Taylor A, Hosseini SM , DCCT/EDIC Research Group, Parving HH, Rossing P, Tarnow L, Ladenvall C, Alhenc-Gelas F, Lefebvre P, Rigalleau V, Roussel R, Tregouet DA, M aestroni A, Maestroni S, Falhammar H, Gu T, M ollsten A, Cimponeriu D, loana M, M ota M, M ota E, Serafinceanu C, Stavarachi M, Hanson RL, Nelson RG, Kretzler M, Colhoun HM , Panduru NM , Gu HF, Brismar K, Zerbini G, Hadjadj S, Marre M , Groop L, Lajer M, Bull SB, Waggott D, Paterson AD, Savage DA, Bain SC, Martin F, Hirschhorn JN, Godson C, Florez JC, Groop PH, M axwell AP: New susceptibility Loci associated with kidney disease in type 1 diabetes. PLoS Genet 2012, 8:e1002921 doi: 10.1371/journal.pgen.1002921; 10.1371/journal.pgen.1002921.

13. Sandholm N, M cKnight AJ, Salem RM, Brennan EP, Forsblom C, Harjutsalo V, M akinen VP, M cKay GJ, Sadlier DM, Williams WW, Martin F, Panduru NM, Tarnow L, Tuomilehto J, Tryggvason K, Zerbini G, Comeau M E, Langefeld CD, FIND Consortium, Godson C, Hirschhorn JN, M axwell AP, Florez JC, Groop $\mathrm{PH}$, FinnDiane Study Group and the GENIE Consortium: Chromosome 2q31.1 associates with ESRD in women with type 1 diabetes. J Am Soc Nephrol 2013, 24:1537-1543 doi: 10.1681/ASN.2012111122; 10.1681/ASN.2012111122.

14. Sandholm N, Forsblom C, M akinen VP, M cKnight AJ, Osterholm AM , He B, Harjutsalo V, Lithovius R, Gordin D, Parkkonen M, Saraheimo M, Thorn LM, Tolonen N, Waden J, Tuomilehto J, Lajer M , Ahlqvist E, M ollsten A, Marcovecchio M L, Cooper J, Dunger D, Paterson AD, Zerbini G, Groop L, SUM M IT Consortium, Tarnow L, Maxwell AP, Tryggvason K, Groop PH, FinnDiane Study Group: Genome-wide association study of urinary albumin excretion rate in patients with type 1 diabetes. Diabetologia 2014, 57:1143-1153 doi: 10.1007/s00125-014-3202-3 [doi].

15••. Iyengar SK, Sedor JR, Freedman BI, Kao WH, Kretzler M, Keller BJ , Abboud HE, Adler SG, Best LG, Bowden DW, Burlock A, Chen YD, Cole SA, Comeau ME, Curtis JM, Divers J, Drechsler C, Duggirala R, Elston RC, Guo X, Huang H, Hoffmann M M , Howard BV, Ipp E, Kimmel PL, Klag MJ, Knowler WC, Kohn 
OF, Leak TS, Leehey DJ , Li M, Malhotra A, Marz W, Nair V, Nelson RG, Nicholas SB, O'Brien SJ , Pahl M V, Parekh RS, Pezzolesi M G, Rasooly RS, Rotimi CN, Rotter JI, Schelling JR, Seldin MF, Shah VO, Smiles AM, Smith M W, Taylor KD, Thameem F, Thornley-Brown DP, Truitt BJ, Wanner C, Weil EJ, Winkler CA, Zager PG, Igo RP, Jr, Hanson RL, Langefeld CD, Family Investigation of Nephropathy and Diabetes (FIND):

Genome-Wide Association and Trans-ethnic Meta-Analysis for Advanced Diabetic Kidney Disease: Family Investigation of Nephropathy and Diabetes (FIND). PLoS Genet 2015, 11:e1005352 doi: 10.1371/journal.pgen.1005352 [doi]. Trans-ethnic GWAS on DKD identified a novel locus between the SCAFBand QNGR3genes.

16•. Pattaro C, Teumer A, Gorski M, Chu AY, Li M, Mijatovic V, Garnaas M, Tin A, Sorice R, Li Y, Taliun D, Olden M , Foster M, Yang Q, Chen M H, Pers TH, Johnson AD, Ko YA, Fuchsberger C, Tayo B, Nalls M, Feitosa MF, Isaacs A, Dehghan A, d'Adamo P, Adeyemo A, Dieffenbach AK, Zonderman AB, Nolte IM, van der M ost PJ, Wright AF, Shuldiner AR, M orrison AC, Hofman A, Smith AV, Dreisbach AW, Franke A, Uitterlinden AG, M etspalu A, Tonjes A, Lupo A, Robino A, Johansson A, Demirkan A, Kollerits B, Freedman BI, Ponte B, Oostra BA, Paulweber B, Kramer BK, Mitchell BD, Buckley BM, Peralta CA, Hayward C, Helmer C, Rotimi CN, Shaffer CM, M uller C, Sala C, van Duijn CM, Saint-Pierre A, Ackermann D, Shriner D, Ruggiero D, Toniolo D, Lu Y, Cusi D, Czamara D, Ellinghaus D, Siscovick DS, Ruderfer D, Gieger C, Grallert H, Rochtchina E, Atkinson EJ, Holliday EG, Boerwinkle E, Salvi E, Bottinger EP, M urgia F, Rivadeneira F, Ernst F, Kronenberg F, Hu FB, Navis GJ , Curhan GC, Ehret GB, Homuth G, Coassin S, Thun GA, Pistis G, Gambaro G, M alerba G, M ontgomery GW, Eiriksdottir G, Jacobs G, Li G, Wichmann HE, Campbell H, Schmidt H, Wallaschofski H, Volzke H, Brenner H, Kroemer HK, Kramer H, Lin H, Leach IM , Ford I, Guessous I, Rudan I, Prokopenko I, Borecki I, Heid IM , Kolcic I, Persico I, Jukema JW, Wilson JF, Felix JF, Divers J, Lambert JC, Stafford JM , Gaspoz JM , Smith JA, Faul JD, Wang JJ, Ding J, Hirschhorn JN, Attia J, Whitfield JB, Chalmers J, Viikari J, Coresh J, Denny JC, Karjalainen J, Fernandes JK, Endlich K, Butterbach K, Keene KL, Lohman K, Portas L, Launer LI, Lyytikainen LP, Yengo L, Franke L, Ferrucci L, Rose LM, Kedenko L, Rao M, Struchalin M, Kleber ME, Cavalieri M, Haun M, Cornelis M C, Ciullo M, Pirastu M, de Andrade M, M cEvoy M A, Woodward M, Adam M, Cocca M, Nauck M , Imboden M, Waldenberger M, Pruijm M, M etzger M, Stumvoll M, Evans MK, Sale M M, Kahonen M, Boban M, Bochud M, Rheinberger M, Verweij N, Bouatia-Naji N, Martin NG, Hastie N, Probst-Hensch N, Soranzo N, Devuyst O, Raitakari O, Gottesman O, Franco OH, Polasek O, Gasparini P, M unroe PB, Ridker PM, $M$ itchell $P$, M untner $P$, M eisinger $C$, Smit JH, ICBP Consortium, AGEN Consortium, CARDIOGRAM, CHARGe-Heart Failure Group, ECHOGen Consortium, Kovacs P, Wild PS, Froguel P, Rettig R, M agi R, Biffar R, Schmidt R, M iddelberg RP, Carroll RJ, Penninx BW, Scott RJ, Katz R, Sedaghat S, Wild SH, Kardia SL, Ulivi S, Hwang SJ, Enroth S, Kloiber S, Trompet S, Stengel B, Hancock S), Turner ST, Rosas SE, Stracke S, Harris TB, Zeller T, Zemunik T, Lehtimaki T, Illig T, Aspelund T, Nikopensius T, Esko T, Tanaka T, Gyllensten U, Volker U, Emilsson V, Vitart V, Aalto V, Gudnason V, Chouraki V, Chen W M , Igl W, Marz W, Koenig W, Lieb W, Loos RJ, Liu Y, Snieder H, Pramstaller PP, Parsa A, O'Connell JR, Susztak K, Hamet P, Tremblay J, de Boer IH, Boger CA, Goessling W, Chasman DI, Kottgen A, Kao WH, Fox CS: Genetic associations at 53 loci highlight cell types and biological pathways relevant for kidney function. Nat Commun 2016, 7:10023 doi: 10.1038/ncomms10023 [doi]. GWAS meta-analysis on eGFR in 133,413 individuals showed that the previously identified rs12917707 in UMODgene was associated with eGFR also in diabetic subjects, and suggests that also the other eGFR loci may be relevant for diabetic individuals. 
17. Fioretto P, Mauer M : Histopathology of diabetic nephropathy. Semin Nephrol 2007, 27:195-207 doi: S0270-9295(07)00014-9 [pii].

18•. Todd JN, Dahlstrom EH, Salem RM, Sandholm N, Forsblom C, FinnDiane Study Group, M cKnight AJ, M axwell AP, Brennan E, Sadlier D, Godson C, Groop PH, Hirschhorn JN, Florez JC: Genetic Evidence for a Causal Role of Obesity in Diabetic Kidney Disease. Diabetes 2015, 64:4238-4246 doi: 10.2337/db150254 [doi]. This Mendelian randomization study suggest that obesity is a causal risk factor for diabetic kidney disease and even ESRD, despite controversial results from the cross-sectional evaluation.

19•. Panduru NM, Sandholm N, Forsblom C, Saraheimo M, Dahlstrom EH, Thorn LM, Gordin D, Tolonen N, Waden J, Harjutsalo V, Bierhaus A, Humpert PM , Groop PH, FinnDiane Study Group: Kidney injury molecule-1 and the loss of kidney function in diabetic nephropathy: a likely causal link in patients with type 1 diabetes. Diabetes Care 2015, 38:1130-1137 doi: 10.2337/dc14-2330 [doi]. This study identified strong genetic determinants for urinary KIM-1 levels, and the Mendelian randomisation suggests that KIM-1 is a causal risk factor for reduced renal function, even when adjusting for the level of albuminuria.

20•. Ahola AJ, Sandholm N, Forsblom C, Harjutsalo V, Dahlstrom E, Groop PH, FinnDiane Study Group: The serum uric acid concentration is not causally linked to diabetic nephropathy in type 1 diabetes. Kidney Int 2017, 91:1178-1185 doi: S0085-2538(16)30757-8 [pii]. Serum uric acid predicted progression of diabetic kidney disease, but using Mendelian Randomisation with a genetic risk score for serum uric acid, this study suggested that serum uric acid may not be causally related to reduced renal function in diabetic individuals, which may challenge the clinical trials on the subject.

21. M onti M C, Lonsdale JT, M ontomoli C, M ontross R, Schlag E, Greenberg DA: Familial risk factors for microvascular complications and differential male-female risk in a large cohort of American families with type 1 diabetes. J Clin Endocrinol M etab 2007, 92:4650-4655 doi: jc.2007-1185 [pii].

22. Arar NH, Freedman BI, Adler SG, Iyengar SK, Chew EY, Davis MD, Satko SG, Bowden DW, Duggirala R, Elston RC, Guo X, Hanson RL, Igo RP,Jr, Ipp E, Kimmel PL, Knowler WC, Molineros J, Nelson RG, Pahl M V, Quade SR, Rasooly RS, Rotter JI, Saad M F, Scavini M, Schelling JR, Sedor JR, Shah VO, Zager PG, Abboud HE, Family Investigation of Nephropathy and Diabetes Research Group: Heritability of the severity of diabetic retinopathy: the FIND-Eye study. Invest Ophthalmol Vis Sci 2008, 49:3839-3845 doi: 10.1167/iovs.07-1633 [doi].

23. Hietala K, Forsblom C, Summanen P, Groop PH, FinnDiane Study Group: Heritability of proliferative diabetic retinopathy. Diabetes 2008, 57:2176-2180 doi: 10.2337/db07-1495; 10.2337/db07-1495.

24. Abhary S, Hewitt AW, Burdon KP, Craig JE: A systematic meta-analysis of genetic association studies for diabetic retinopathy. Diabetes 2009, 58:2137-2147 doi: 10.2337/db09-0059 [doi].

25•. Porta M, Toppila I, Sandholm N, Hosseini SM , Forsblom C, Hietala K, Borio L, Harjutsalo V, Klein BE, Klein R, Paterson AD, DCCT/EDIC Research Group, Groop PH, FinnDiane Study Group: Variation in SLC19A3 and Protection From Microvascular Damage in Type 1 Diabetes. Diabetes 2016, 65:10221030 doi: 10.2337/db15-1247 [doi]. Candidate gene study on thiamine (Vitamin $\mathbf{B}_{1}$ ) transporters 
found association with diabetic retinopathy, and when combined with replication studies, the variants were genome-wide significantly associated with the joint microvascular endpoint of retinopathy and ESRD.

26. Fu YP, Hallman DM, Gonzalez VH, Klein BE, Klein R, Hayes M G, Cox NJ, Bell GI, Hanis CL: Identification of Diabetic Retinopathy Genes through a Genome-Wide Association Study among M exican-Americans from Starr County, Texas. J Ophthalmol 2010, 2010:10.1155/2010/861291. Epub 2010 Sep 2 doi: 10.1155/2010/861291 [doi].

27. Grassi M A, Tikhomirov A, Ramalingam S, Below JE, Cox NJ, Nicolae DL: Genome-wide meta-analysis for severe diabetic retinopathy. Hum M ol Genet 2011, 20:2472-2481 doi: 10.1093/hmg/ddr121 [doi].

28. Huang YC, Lin JM, Lin HJ, Chen CC, Chen SY, Tsai CH, Tsai FJ: Genome-wide association study of diabetic retinopathy in a Taiwanese population. Ophthalmology 2011, 118:642-648 doi: 10.1016/j.ophtha.2010.07.020 [doi].

29. Sheu WH, Kuo JZ, Lee IT, Hung YJ, Lee WJ, Tsai HY, Wang JS, Goodarzi M O, Klein R, Klein BE, Ipp E, Lin SY, Guo X, Hsieh CH, Taylor KD, Fu CP, Rotter JI, Chen YD: Genome-wide association study in a Chinese population with diabetic retinopathy. Hum Mol Genet 2013, 22:3165-3173 doi: 10.1093/hmg/ddt161 [doi].

30. Awata T, Yamashita H, Kurihara S, M orita-Ohkubo T, M iyashita Y, Katayama S, M ori K, Yoneya S, Kohda M, Okazaki Y, M aruyama T, Shimada A, Yasuda K, Nishida N, Tokunaga K, Koike A: A genome-wide association study for diabetic retinopathy in a Japanese population: potential association with a long intergenic non-coding RNA. PLOS One 2014, 9:e111715 doi: 10.1371/journal.pone.0111715 [doi].

31••. Burdon KP, Fogarty RD, Shen W, Abhary S, Kaidonis G, Appukuttan B, Hewitt AW, Sharma S, Daniell M, Essex RW, Chang JH, Klebe S, Lake SR, Pal B, Jenkins A, Govindarjan G, Sundaresan P, Lamoureux EL, Ramasamy K, Pefkianaki M, Hykin PG, Petrovsky N, Brown M A, Gillies M C, Craig JE: Genome-wide association study for sight-threatening diabetic retinopathy reveals association with genetic variation near the GRB2 gene. Diabetologia 2015, 58:2288-2297 doi: 10.1007/s00125-015-3697-2 [doi]. GWAS on retinopathy in Australian individuals with T2D found variants near GRB2 gene associated with retinopathy. The findings replicated in individuals with T1D, T2D, and Indian individuals with T2D, resulting in a genome-wide significant association after meta-analysis.

32. M cAuley AK, Wang JJ, Dirani M, Connell PP, Lamoureux E, Hewitt AW: Replication of genetic loci implicated in diabetic retinopathy. Invest Ophthalmol Vis Sci 2014, 55:1666-1671 doi: 10.1167/iovs.13-13559 [doi].

33. Hosseini SM, Boright AP, Sun L, Canty AJ, Bull SB, Klein BE, Klein R, DCCT/EDIC Research Group, Paterson $A D$ : The association of previously reported polymorphisms for microvascular complications in a meta-analysis of diabetic retinopathy. Hum Genet 2015, 134:247-257 doi: 10.1007/s00439-014-15172 [doi].

34. Cheung CY, Hui EY, Lee CH, Kwok KH, Gangwani RA, Li KK, Chan JC, Woo YC, Chow WS, Yuen M M, Wong $\mathrm{RL}$, Fong $\mathrm{CH}$, Xu A, Wong DS, Sham PC, Lam KS: Impact of Genetic Loci Identified in Genome-Wide 
Association Studies on Diabetic Retinopathy in Chinese Patients With Type 2 Diabetes. Invest Ophthalmol Vis Sci 2016, 57:5518-5524 doi: 10.1167/iovs.16-20094 [doi].

35. Shtir C, Aldahmesh MA, Al-Dahmash S, Abboud E, Alkuraya H, Abouammoh MA, Nowailaty SR, AlThubaiti G, Naim EA, ALYounes B, Binhumaid FS, ALOtaibi AB, Altamimi AS, Alamer FH, Hashem M, Abouelhoda M, M onies D, Alkuraya FS: Exome-based case-control association study using extreme phenotype design reveals novel candidates with protective effect in diabetic retinopathy. Hum Genet 2016, 135:193-200 doi: 10.1007/s00439-015-1624-8 [doi].

36. Ung C, Sanchez AV, Shen L, Davoudi S, Ahmadi T, Navarro-Gomez D, Chen CJ, Hancock H, Penman A, Hoadley S, Consugar M, Restrepo C, Shah VA, Arboleda-Velasquez JF, Sobrin L, Gai X, Kim LA: Whole exome sequencing identification of novel candidate genes in patients with proliferative diabetic retinopathy. Vision Res 2017, doi: S0042-6989(17)30054-8 [pii].

37. Tesfaye S, Boulton AJ, Dyck PJ, Freeman R, Horowitz M, Kempler P, Lauria G, Malik RA, Spallone V, Vinik A, Bernardi L, Valensi P, Toronto Diabetic Neuropathy Expert Group: Diabetic neuropathies: update on definitions, diagnostic criteria, estimation of severity, and treatments. Diabetes Care 2010, 33:22852293 doi: 10.2337/dc10-1303 [doi].

38. Wu S, Han Y, Hu Q, Zhang X, Cui G, Li Z, Guan Y: Effects of Common Polymorphisms in the MTHFR and ACE Genes on Diabetic Peripheral Neuropathy Progression: a Meta-Analysis. M ol Neurobiol 2016, doi: 10.1007/s12035-016-9823-4 [doi].

39•. Meng W, Deshmukh HA, van Zuydam NR, Liu Y, Donnelly LA, Zhou K, Wellcome Trust Case Control Consortium 2 (WTCCC2), Surrogate Markers for M icro- and Macro-Vascular Hard Endpoints for Innovative Diabetes Tools (SUM M IT) Study Group, M orris AD, Colhoun HM, Palmer CN, Smith BH: A genome-wide association study suggests an association of Chr8p21.3 (GFRA2) with diabetic neuropathic pain. Eur J Pain 2015, 19:392-399 doi: 10.1002/ejp.560 [doi]. The first GWAS on painful neuropathy identified $19 \%$ of the eligible cohort having painful neuropathy, indicated $11 \%$ heritability for the trait, and suggested a genetic association near GFRA2.

40. Meng W, Deshmukh HA, Donnelly LA, Wellcome Trust Case Control Consortium 2 (WTCCC2), Surrogate markers for M icro- and M acro-vascular hard endpoints for Innovative diabetes Tools (SUM M IT) study group, Torrance N, Colhoun HM , Palmer CN, Smith BH: A Genome-wide Association Study Provides Evidence of Sex-specific Involvement of Chr1p35.1 (ZSCAN20-TLR12P) and Chr8p23.1 (HM GB1P46) With Diabetic Neuropathic Pain. EBioM edicine 2015, 2:1386-1393 doi: 10.1016/j.ebiom.2015.08.001 [doi].

41. Tuomilehto J, Borch-Johnsen K, M olarius A, Forsen T, Rastenyte D, Sarti C, Reunanen A: Incidence of cardiovascular disease in Type 1 (insulin-dependent) diabetic subjects with and without diabetic nephropathy in Finland. Diabetologia 1998, 41:784-790.

42. Earle K, Walker J, Hill C, Viberti G: Familial clustering of cardiovascular disease in patients with insulindependent diabetes and nephropathy. N Engl J Med 1992, 326:673-677 doi: 10.1056/NEJM 199203053261005 [doi]. 
43. Lange LA, Bowden DW, Langefeld CD, Wagenknecht LE, Carr JJ, Rich SS, Riley WA, Freedman BI:

Heritability of carotid artery intima-medial thickness in type 2 diabetes. Stroke 2002, 33:1876-1881.

44. Qi L, Parast L, Cai T, Powers C, Gervino EV, Hauser TH, Hu FB, Doria A: Genetic susceptibility to coronary heart disease in type 2 diabetes: 3 independent studies. J Am Coll Cardiol 2011, 58:2675-2682.

45. Cox AJ, Hsu FC, Ng M C, Langefeld CD, Freedman BI, Carr JJ, Bowden DW: Genetic risk score associations with cardiovascular disease and mortality in the Diabetes Heart Study. Diabetes Care 2014, 37:11571164 doi: $10.2337 /$ dc13-1514 [doi].

46. Qi L, Qi Q, Prudente S, M endonca C, Andreozzi F, di PN, Sturma M, Novelli V, M annino GC, Formoso G, Gervino EV, Hauser TH, Muehlschlegel JD, Niewczas MA, Krolewski AS, Biolo G, Pandolfi A, Rimm E, Sesti G, Trischitta V, Hu F, Doria A: Association between a genetic variant related to glutamic acid metabolism and coronary heart disease in individuals with type 2 diabetes. JAM A 2013, 310:821-828.

47•. Shah HS, Gao H, M orieri M L, Skupien J, M arvel S, Pare G, Mannino GC, Buranasupkajorn P, M endonca C, Hastings T, Marcovina SM, Sigal RJ, Gerstein HC, Wagner MJ, M otsinger-Reif AA, Buse JB, Kraft P, M ychaleckyj JC, Doria A: Genetic Predictors of Cardiovascular M ortality During Intensive Glycemic Control in Type 2 Diabetes: Findings From the ACCORD Clinical Trial. Diabetes Care 2016, 39:19151924 doi: dc16-0285 [pii]. This GWAS study identified two genetic risk factors for cardiovascular mortality within intensively treated diabetic individuals, with each variant associated with threefold risk of mortality. Supporting evidence for mortality under tight glycemic control was obtained from two other studies.

48. Shah HS, M orieri ML, M arcovina SM, Sigal RJ, Gerstein HC, Wagner MJ, M otsinger-Reif AA, Buse JB, Kraft P, M ychaleckyj JC, Doria A: Modulation of GLP-1 Levels by a Genetic Variant That Regulates the Cardiovascular Effects of Intensive Glycemic Control in ACCORD. Diabetes Care 2017, doi: dc171638 [pii].

49. Chheda H, Palta P, Pirinen M, M cCarthy S, Walter K, Koskinen S, Salomaa V, Daly M, Durbin R, Palotie A, Aittokallio T, Ripatti S: Whole-genome view of the consequences of a population bottleneck using 2926 genome sequences from Finland and United Kingdom. Eur J Hum Genet 2017, 25:477-484 doi: 10.1038/ ejhg.2016.205 [doi].

50. Bell CG, Teschendorff AE, Rakyan VK, Maxwell AP, Beck S, Savage DA: Genome-wide DNA methylation analysis for diabetic nephropathy in type 1 diabetes mellitus. BM C M ed Genomics 2010, 3:33-8794-333 doi: 10.1186/1755-8794-3-33 [doi].

51 •. Agardh E, Lundstig A, Perfilyev A, Volkov P, Freiburghaus T, Lindholm E, Ronn T, Agardh CD, Ling C: Genome-wide analysis of DNA methylation in subjects with type 1 diabetes identifies epigenetic modifications associated with proliferative diabetic retinopathy. BM C M ed 2015, 13:182-015-0421-5 doi: 10.1186/s12916-015-0421-5 [doi]. Epigenome-wide DNA methylation study on 28 cases with diabetic retinopathy and 30 non-PDR controls identified differential methylation in 233 genes. 


\section{Figure legends}

Figure 1: Loci reaching genome-wide significant association $\left(p<5 \times 10^{-8}\right)$ with renal complications in diabetes. Effect size estimates are given as odds ratios for diabetic kidney disease (DKD) and end stage renal disease (ESRD), but as $\beta$ for continuous traits ( $\beta$ [log(AER)], $10 \times \beta$ [log(eGFR)]). References for the loci: rs7583877 (AFF3) and rs12437854 (RGM A/M CTP2) [12]; rs4972593 (CDCA7/SP3)[13]; rs12523833 (SCAF8/CNKSR3)[15]; rs1564939 (GLRA3)[14]; rs12917707 (UM OD)[16]. 